\title{
Long-term outcome of severe paediatric pulmonary Langerhans cell histiocytosis: do not underestimate lung plasticity
}

\author{
Amira Benattia, ${ }^{1}$ Céline Delestrain, ${ }^{2}$ Jean Donadieu, ${ }^{3}$ Abdellatif Tazi ${ }^{1,4}$
}

${ }^{1}$ National Reference Centre for Histiocytoses, Pulmonology Department, Hôpital Saint-Louis, Assistance Publique - Hopitaux de Paris, Paris, Île-de-France, France

${ }^{2}$ Pediatrics Department, Centre Hospitalier Intercommunal de Créteil, Creteil, île-de-France, France

${ }^{3}$ National Reference Centre for Histiocytoses, Paediatric Haemato-Oncology Department, Hôpital Trousseau, Assistance Publique - Hopitaux de Paris, Paris, île-de-France, France ${ }^{4}$ INSERM U976, Institut de Recherche Saint-Louis, Université de Paris, PARIS, Îlede-France, France

\section{Correspondence to}

Dr Abdellatif Tazi;

abdellatif.tazi@aphp.fr

Accepted 14 March 2021

\section{DESCRIPTION}

A 20-year-old man was referred for isolated pulmonary Langerhans cell histiocytosis (PLCH). He had experienced left-sided pneumothorax at 7 years of age. Lung high-resolution CT (HRCT) showed associated cystic lesions predominating in the lung bases. The pneumothorax was managed by surgical pleurodesis, and the diagnosis of $\mathrm{LCH}$ was confirmed on a lung biopsy obtained during the same procedure. The patient received a combination of vinblastine and corticosteroids for 1 year. After treatment, he was asymptomatic, lung function was slightly altered (forced vital capacity (FVC) 75\% of predicted values), and lung HRCT was unchanged (figure 1A,B). Twelve years after diagnosis, he was still symptom-free, and his physical examination was normal. He never smoked. Lung function showed: FVC that was $80 \%$, a forced expiratory volume in $1 \mathrm{~s}$ that was $76 \%$, and a diffusing capacity of carbon monoxide $\left(\mathrm{D}_{\mathrm{LCO}}\right)$ that was $80 \%$ of the predicted values. The lung HRCT 10 years after treatment showed impressive regression of cystic lesions (figure 1B,C).

A 13-year-old girl suffered from severe lung involvement in the context of multisystem LCH. Her lung condition moderately improved after 6 monthly cycles of cladribine, as previously reported. ${ }^{1}$ Lung HRCT findings 2 years after treatment are shown in figure 2A. During the follow-up, she had residual liver and pituitary LCH involvement sequelae. Her treatment consisted only of hormonal substitution. At the age of 19 years, she was referred to our adult department for further management. She had never smoked. The clinical examination was unremarkable. Lung function measurements showed moderate air trapping and a $\mathrm{D}_{\mathrm{LCO}}$ that was $66 \%$ of the predicted value. Lung HRCT performed 6 years after cladribine treatment showed a striking improvement in cystic lesions (figure 2B).

Little is known about the long-term outcome of lung involvement in the course of LCH occurring in paediatric patients. Here, we report two adult patients with a history of childhood diffuse cystic PLCH that dramatically improved in adulthood. Vinblastine has limited efficacy in PLCH. We previously reported that cladribine might partially improve cystic lesions in selected cases. ${ }^{2}$ Because the impressive resolution of cystic lesions on lung HRCT occurred long after these treatments, which either had no or moderate shortterm effects, ${ }^{1}$ the striking improvement observed in adulthood was most likely due to natural lung compensation and growth.

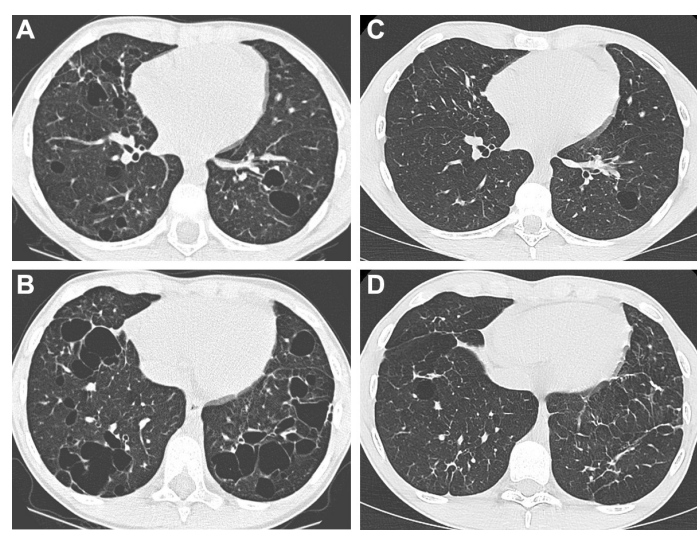

Figure 1 Transverse sections of high-resolution CT scans of the chest at the lung window (widths of -600 to $1600 \mathrm{HU})$. (A, B) At the end of 1 year of treatment with vinblastine and corticosteroids, diffuse pulmonary cystic lesions were observed. (C, D) In adulthood, 10 years after treatment, the lung abnormalities had dramatically improved.

Schematically, human lung growth follows two postnatal phases. ${ }^{3}$ The first period, occurring after birth, is characterised by an increase in lung aeration. After 2 years of age and until young adulthood, the lung volume increases in parallel with body growth. The lung vascular volume is also strongly augmented during this period, ${ }^{3}$ which probably explains the low alteration in the patients' $\mathrm{D}_{\mathrm{LCO}}$ observed in adulthood. In addition, the plasticity of the lung tissues and a compensatory alveolar formation process may have accounted for the impressive improvement observed in these two patients who had diffuse
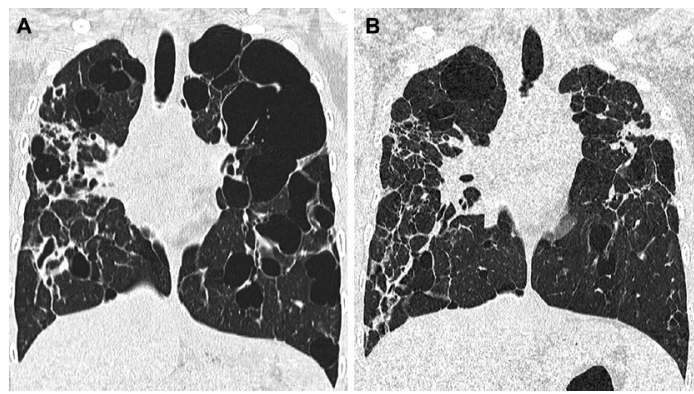

Figure 2 Coronal high-resolution CT scans of the chest at the lung window (widths of -600 to $1600 \mathrm{HU}$ ). (A) Two years after cladribine treatment, showing persisting cystic lung lesions. (B) In adulthood, 6 years after treatment, cystic lung lesions had impressively improved. 
cystic PLCH during their childhoods. ${ }^{3}$ The fact that both patients were sustainably non-smokers also probably favoured the repair of their initial lung damage.

Learning points

Cystic lung involvement of paediatric-onset pulmonary Langerhans cell histiocytosis may be extensive. However, these cases can dramatically improve in adulthood.

- The high plasticity of the lung tissues and a compensatory alveolar formation process in child developing lung may explain this impressive outcome.
Contributors $C D, J D$ managed the patients during their childhoods. $A B$ and $A T$ managed the patients as adults. All authors contributed to writing the manuscript. All authors have approved the version of the manuscript submitted for publication.

Funding The authors have not declared a specific grant for this research from any funding agency in the public, commercial or not-for-profit sectors.

Competing interests None declared.

Patient consent for publication Obtained.

Provenance and peer review Not commissioned; externally peer reviewed.

\section{REFERENCES}

1 Epaud R, Ducou Le Pointe H, Fasola S, et al. Cladribine improves lung cysts and pulmonary function in a child with histiocytosis. Eur Respir J 2015;45:831-3.

2 Lorillon G, Bergeron A, Detourmignies L, et al. Cladribine is effective against cystic pulmonary Langerhans cell histiocytosis. Am J Respir Crit Care Med 2012;186:930-2.

3 Burri PH. Structural aspects of postnatal lung development - alveolar formation and growth. Biol Neonate 2006;89:313-22.

Copyright 2021 BMJ Publishing Group. All rights reserved. For permission to reuse any of this content visit https://www.bmj.com/company/products-services/rights-and-licensing/permissions/

BMJ Case Report Fellows may re-use this article for personal use and teaching without any further permission.

Become a Fellow of BMJ Case Reports today and you can:

- Submit as many cases as you like

- Enjoy fast sympathetic peer review and rapid publication of accepted articles

- Access all the published articles

Re-use any of the published material for personal use and teaching without further permission

Customer Service

If you have any further queries about your subscription, please contact our customer services team on +44 (0) 2071111105 or via email at support@bmj.com.

Visit casereports.bmj.com for more articles like this and to become a Fellow 